DOI: $10.31393 /$ reports-vnmedical-2021-25(2)-21

UDC: $611.01: 159.953 .4: 616-053$

\title{
THE USE OF MNEMONICS FOR BETTER ACADEMIC PERFORMANCE OF MEDICAL UNIVERSITY STUDENTS IN THE STUDY OF ANATOMICAL TERMS
}

Cherepakha O. L., Gadzhula N. G., Rekun T. O.

National Pirogov Memorial Medical University, Vinnytsya (Pyrogov street, 56, Vinnytsia, Ukraine, 21018)

Responsible for correspondence: e-mail: cherepakha79@gmail.com

Received: April 22, 2021; Accepted: May 31, 2021

\begin{abstract}
Annotation. Mnemonics are a combination of special methods and techniques that make it easier to memorize the necessary information and increase the amount of memory by forming associations. The aim of the work is to develop techniques that will help medical students effectively learn anatomical terms by facilitating the memorization of large amounts of information. In this article, we used the following mnemonic techniques: first letter mnemonics or acronyms and the "Comparison" method - to identify common features in the studied and well-known material, namely the similarity in form. This article includes mnemonics that will help to easily learn the following terms namely the anatomy of the skeleton bones for memorizing the bones of the medial wall of the orbit, the bones in the nasal septum, the wrist bones, the ankle tarsal bones, recognition of thoracic vertebrae from the lumbar, cranial bones, upper limb bones, bones of the lower limb, the vertebral regions, the hand, the arm bones and the bone projections. Also included are mnemonics on the anatomy of the cranial nerves that pass through the superior orbital fissure and branches of the facial nerve, mnemonics on the anatomy of the peripheral nervous system, namely somatic nerve plexuses, which include the brachial plexus branches. Also included are mnemonics on the anatomy of the upper limbs muscles, namely the muscles that form the rotator cuff in the shoulder, muscles involved in elbow flexion and the anterior flexor muscles of the forearm and mnemonics on the anatomy of the trunk muscles, namely the paired erector spinae muscles and abdominal muscles. Finally, this article includes a mnemonic on the anatomy of the male reproductive system, namely the layers of the scrotum. In the future, new mnemonics will be developed that relate to splanchnology, anatomy of the central nervous system, anatomy of the sensory organs and anatomy of the cardiovascular system, which were not listed above.
\end{abstract}

Keywords: mnemonics, mnemonic technique, anatomical terms, English-speaking students.

\section{Introduction}

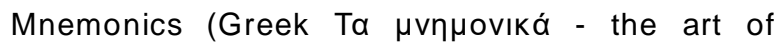
memorization), mnemonic techniques are a combination of special methods and techniques that make it easier to memorize the necessary information and increase the amount of memory by forming associations. Words with an unknown, abstract meaning are difficult for most people to remember. If such a word is "memorized", then it disappears from memory after a few days. For lasting and at the same time easy memorization, the word should be filled with meaning (mnemonic methods) - something that is associated with specific vivid visual, sound images, with strong sensations.

Mnemonics is one of the oldest applied disciplines. The first known texts on mnemonics were created by the ancient Greeks. The experience gained over time in the application of mnemonic techniques began to be used in teaching various disciplines. Teaching mnemonics in medical school has become a widespread practice, with its inclusion in textbooks and articles [3, 4, 5, 6, 9, 11].

The aim of the work was to develop techniques that will help students of medical institutions to effectively learn anatomical terms by facilitating the memorization of large amounts of information.

\section{Materials and methods}

Mnemonic systems are special technologies or strategies that are deliberately used to improve memory [8].
Mnemonic methods in anatomy are a special technique that is designed to improve the memorization of terminology [2].

The formation of associations has a good effect on the brain work, improving a person's ability to systematize knowledge, helps to memorize large amounts of information faster and more efficiently [10].

In this article, we used the following mnemonic techniques:

- Mnemonics by first letters or acronyms. This method is based on taking the first letter of the name of each word that needs to be memorized in general or in a certain sequence, and composing a new word or phrase. For best results when played back in memory, the phrase should make sense; it should also not be too long and witty [2].

- Comparison method - identifying common features in the studied and well-known material. Similarity in shape, for example, establishing the similarity of the cuboid and sphenoid bones of the feet with parts of the accordion to memorize their location [9].

Three basic principles of mnemonics (the use of associations, encoded information and the formation of an emotional attitude) are often used in pedagogical mnemonics and can be successfully integrated into the process of studying anatomy [7].

\section{Results. Discussion}

In order to memorize the bones of the medial wall of the orbit, students are encouraged to study the mnemonic 
phrase: My Little Eye Sits in the orbit, where the first letters of each word of this sentence correspond to the first letters of the bones of the medial wall of the orbit, that is, $\mathbf{M}$ in the word My corresponds to the first letter in Maxilla (frontal process), L in Little corresponds to the first letter in Lacrimal, E in Eye corresponds to the first letter in Ethmoid, $\mathbf{S}$ in Sits corresponds to the first letter in Sphenoid (body) [1].

In order to memorize the bones in the nasal septum, students are encouraged to study the mnemonic phrase: My Very Fine Nasal SEPtum, where the first letters of each word of this sentence correspond to the first letters of the bones in the nasal septum, that is, $\mathbf{M}$ in the word $\mathbf{M y}$ corresponds to the first letter in Maxilla, $\mathbf{V}$ in the word Very corresponds to the first letter in Vomer, $\mathbf{F}$ in the word Fine corresponds to the first letter in Frontal, $\mathbf{N}$ in the word Nasal corresponds to the first letter in Nasal, $\mathbf{S}$ in the word SEPtum corresponds to the first letter in Sphenoid, $\mathbf{E}$ in the word SEPtum corresponds to the first letter in Ethmoid, $\mathbf{P}$ in the word SEPtum corresponds to the first letter in the Palatine (oxford medical) [1].

In order to memorize the wrist bones, students are encouraged to study the mnemonic phrase: She Likes To Play, Try To Catch Her, where the first letters of each word of this sentence correspond to the first letters of the wrist bones, that is, $\mathbf{S}$ in the word She corresponds to the first letter in Scaphoid, $\mathbf{L}$ in the word Likes corresponds to the first letter in Lunate, $\mathbf{T}$ in the word To corresponds to the first letter in Triquetrum, $\mathbf{P}$ in the word Play corresponds to the first letter in Pisiform, $\mathbf{T}$ in the word Try corresponds to the first letter in Trapezium, $\mathbf{T}$ in the word To corresponds to the first letter in Trapezoid, $\mathbf{C}$ in the word Catch corresponds to the first letter in Capitate, $\mathbf{H}$ in the word Her corresponds to the first letter in Hamate (oxford medical) [1].

In order to memorize the wrist bones, students can learn an alternative mnemonic phrase: Stop Letting Those People Touch The Cadaver's Hand, where the first letters of each word of this sentence correspond to the first letters of the wrist bones, that is, $\mathbf{S}$ in the word Stop corresponds to the first letter in Scaphoid, $\mathbf{L}$ in the word Letting corresponds to the first letter in Lunate, $\mathbf{T}$ in the word Those corresponds to the first letter in Triquetrum, $\mathbf{P}$ in the word People corresponds to the first letter in Pisiform, $\mathbf{T}$ in the word Touch corresponds to the first letter in Trapezium, $\mathbf{T}$ in the word The corresponds to the first letter in Trapezoid, $\mathbf{C}$ in the word Cadaver's corresponds to the first letter in Capitate, $\mathbf{H}$ in the word Hand corresponds to the first letter in Hamate (oxford medical) [1].

In order to memorize the ankle tarsal bones, students are encouraged to learn the mnemonic phrase: Tiger Cubs Need MILC, where the first letters of each word in this sentence correspond to the first letters of the ankle tarsal bones, namely $\mathbf{T}$ in the word Tiger corresponds to the first letter in Talus, $\mathbf{C}$ in the word Cubs corresponds to the first letter in Calcaneus, $\mathbf{N}$ in the word Need corresponds to the first letter in Navicular, $\mathbf{M}$ in the word MILC corresponds to

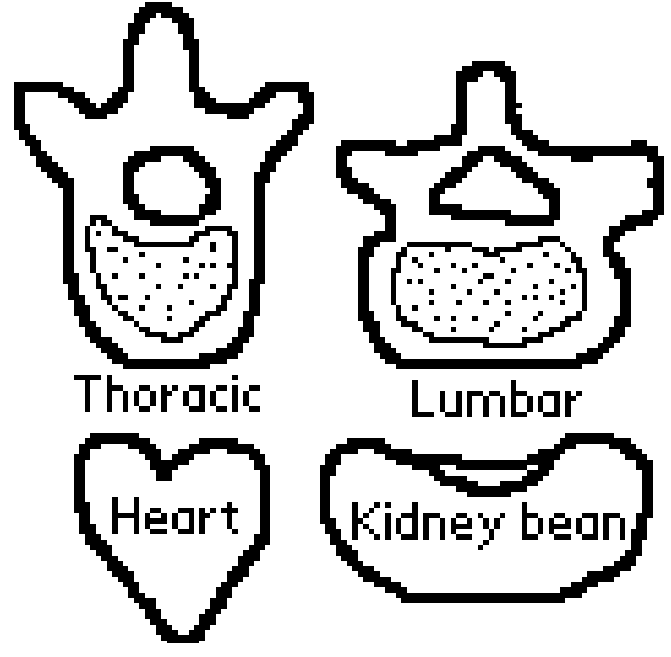

Fig. 1. Recognition of thoracic and lumbar vertebrae.

the first letter in Medial cuneiform, I in the word MILC corresponds to the first letter in Intermediate cuneiform, $\mathbf{L}$ in the word MILC corresponds to the first letter in Lateral cuneiform, $\mathbf{C}$ in the word MILC corresponds to the first letter in Cuboid.

Vertebrae: To recognize the thoracic vertebrae from the lumbar vertebrae, remember that the thoracic vertebrae are heart-shaped because the heart is located in the chest. The lumbar vertebrae are kidney-shaped because the kidneys are located in the lumbar region (Fig. 1).

In order to memorize the cranial bones, students are encouraged to learn the mnemonic phrase: PEST OF 6, where the first letters of each word of this sentence correspond to the first letters of the cranial bones, namely $\mathbf{P}$ in the word PEST corresponds to the first letter in Parietal, $\mathbf{E}$ in the word PEST corresponds to the first letter in Ethmoid, $\mathbf{S}$ in the word PEST corresponds to the first letter in Sphenoid, $\mathbf{T}$ in the word PEST corresponds to the first letter in Temporal, $\mathbf{O}$ in the word OF corresponds to the first letter in Occipital, $\mathbf{F}$ in the word OF corresponds to the first letter in Frontal. $\mathbf{6}$ just reminds you to remember $\mathbf{6}$ bones.

In order to memorize the cranial bones, students can learn an alternative mnemonic phrase: Fat People Only Eat Thick Steak, where the first letters of each word of this sentence correspond to the first letters of the cranial bones, namely $\mathbf{F}$ in the word Fat corresponds to the first letter in Frontal, $\mathbf{P}$ in the word People corresponds to the first letter in Parietal, $\mathbf{O}$ in the word Only corresponds to the first letter in Occipital, $\mathbf{E}$ in the word Eat corresponds to the first letter in Ethmoid, $\mathbf{T}$ in the word Thick corresponds to the first letter in Temporal, $\mathbf{S}$ in the word Steak corresponds to the first letter in Sphenoid.

In order to memorize the bones of the upper limb and the order of their location from proximal to distal, students are encouraged to learn the mnemonic phrase: How Rare U Cook Mesquite Pork, where the first letters of each word in this sentence correspond to the first letters of the upper limb bones, namely $\mathbf{H}$ in the word How corresponds to the 
first letter in Humerus, $\mathbf{R}$ in the word Rare corresponds to the first letter in Radius, $\mathbf{U}$ in the word $\mathbf{U}$ corresponds to the first letter in Ulna, C in the word Cook corresponds to the first letter in Carpal bones, $\mathbf{M}$ in the word Mesquite corresponds to the first letter in Metacarpal bones, $\mathbf{P}$ in the word Pork corresponds to the first letter in Phalanges.

In order to memorize the bones of the lower limb and the order of their location from proximal to distal students are encouraged to learn the mnemonic phrase: From Pennies To Fives They May Pay, where the first letters of each word of this sentence correspond to the first letters of the lower extremity bones, namely $\mathbf{F}$ in the word From corresponds to the first letter in Femur, $\mathbf{P}$ in the word Pennies corresponds to the first letter in Patella, $\mathbf{T}$ in the word To corresponds to the first letter in Tibia, $\mathbf{F}$ in the word Fives corresponds to the first letter in Fibula, $\mathbf{T}$ in the word They corresponds to the first letter in Tarsal bones, $\mathbf{M}$ in the word May corresponds to the first letter in Metatarsal bones, $\mathbf{P}$ in the word Pay corresponds to the first letter in Phalanges.

In order to memorize the vertebral regions and the order of their location from the superior part of the spine to the inferior part, students are encouraged to learn the mnemonic phrase: Can The Ladies Stand Comfortably, where the first letters of each word of this sentence correspond to the first letters of vertebral sections, namely C in the word Can corresponds to the first letter in Cervical, $\mathbf{T}$ in the word The corresponds to the first letter in Thoracic, $\mathbf{L}$ in the word Ladies corresponds to the first letter in Lumbar, $\mathbf{S}$ in the word Stand corresponds to the first letter in Sacral, $\mathbf{C}$ in the word Comfortably corresponds to the first letter in Coccygeal.

In order to remember the bones of the hand and the order of their location from the distal end of the fingertips to the wrist, students are encouraged to learn the mnemonic phrase: Please Make Cookies, where the first letters of each word of this sentence correspond to the first letters of the hand bones, namely $\mathbf{P}$ in the word Please corresponds to the first letter in Phalanges, $\mathbf{M}$ in the word Make corresponds to the first letter in Metacarpal bones, $\mathbf{C}$ in the word Cookies corresponds to the first letter in Carpal bones.

In order to memorize the bones of the arm, students are encouraged to learn the mnemonic phrase: Ultra Red Hair, where the first letters of each word of this sentence correspond to the first letters of the bones of the hand, namely $\mathbf{U}$ in the word Ultra corresponds to the first letter in Ulna, $\mathbf{R}$ in the word Red corresponds to the first letter in Radius, $\mathbf{H}$ in the word Hair corresponds to the first letter in Humerus.

In order to remember the projections of the bone, students are encouraged to study the mnemonic phrase: People Take Teaspoons Temporarily Causing Constipation, where the first letters of each word in this sentence correspond to the first letters of the bone projections, namely $\mathbf{P}$ in the word People corresponds to the first letter in Process, $\mathbf{T}$ in the word Take corresponds to the first letter in Tubercle, $\mathbf{T}$ in the word Teaspoons corresponds to the first letter in Tuberosity, $\mathbf{T}$ in the word Temporarily corresponds to the first letter in Trochanter, C in the word Causing corresponds to the first letter in Condyle, $\mathbf{C}$ in the word Constipation corresponds to the first letter in Crest.

In order to remember the nerves passing through the superior orbital fissure, students are encouraged to study the mnemonic phrase: Live Frankly To See Absolutely No Insult, where the first letters of each word in this sentence correspond to the first letters of the nerves, namely $\mathbf{L}$ in the word Live corresponds to the first letter in Lacrimal nerve, $\mathbf{F}$ in Frankly corresponds to the first letter in Frontal nerve, $\mathbf{T}$ in To corresponds to the first letter in Trochlear nerve, $\mathbf{S}$ in See corresponds to the first letter in Superior division of oculomotor nerve, A in Absolutely corresponds to the first letter in Abducens nerve, $\mathbf{N}$ in the word No corresponds to the first letter in the Nasociliary nerve, $\mathbf{I}$ in the word Insult corresponds to the first letter in the Inferior division of the oculomotor nerve (oxford medical) [1].

In order to memorize the branches of the facial nerve, students are encouraged to study the mnemonic phrase: Ten Zulus Bought My Cat, where the first letters of each word in this sentence correspond to the first letters of the branches, namely $\mathbf{T}$ in Ten corresponds to the first letter in Temporal, $\mathbf{Z}$ in Zulus corresponds to the first letter in Zygomatic, B in the word Bought corresponds to the first letter in Buccal, $\mathbf{M}$ in the word $\mathbf{M y}$ corresponds to the first letter in Mandibular, $\mathbf{C}$ in the word Cat corresponds to the first letter in Cervical (oxford medical) [1].

In order to memorize the brachial plexus branches, students are encouraged to study the mnemonic phrase: My Aunt Raped My Uncle, where the first letters of each word in this sentence correspond to the first letters of the branches, namely $\mathbf{M}$ in $\mathbf{M y}$ corresponds to the first letter in Musculocutaneous, A in Aunt corresponds to the first letter in Axillary, $\mathbf{R}$ in the word Raped corresponds to the first letter in Radial, $\mathbf{M}$ in the word $\mathbf{M y}$ corresponds to the first letter in Median, $\mathbf{U}$ in the word Uncle corresponds to the first letter in Ulnar.

In order to remember which muscles form the rotator cuff in the shoulder, students are encouraged to learn the mnemonic word: SITS, where the first letters of this word correspond to the first letters of the muscles forming the rotator cuff, namely $\mathbf{S}$ in the word SITS corresponds to the first letter in Supraspinatus, I in the word SITS corresponds to the first letter in Infraspinatus, $\mathbf{T}$ in the word SITS corresponds to the first letter in Teres minor, $\mathbf{S}$ in the word SITS corresponds to the first letter in Subscapularis.

In order to remember which muscles are involved in elbow flexion, students are encouraged to learn the mnemonic phrase: 3 B's Bend the elbow, where the first letters of this word correspond to the first letters of the muscles involved in elbow flexion, namely the first $\mathbf{B}$ this is Biceps, the second $\mathbf{B}$ is Brachialis, the third $\mathbf{B}$ is Brachioradialis (oxford medical) [1]. 
In order to memorize the anterior flexor muscles of the forearm, students are encouraged to learn the mnemonic phrase: Cats Run Circles Under Dogs Stomachs, where the first letters of each word in this sentence correspond to the first letters of the muscle, namely $\mathbf{C}$ in the word Cats corresponds to the first letter in Carpi, $\mathbf{R}$ in the word Run corresponds to the first letter in Radialis, $\mathbf{C}$ in the word Circles corresponds to the first letter in Carpi, $\mathbf{U}$ in the word Under corresponds to the first letter in Ulnaris, D in the word Dogs corresponds to the first letter in Digitorum, $\mathbf{S}$ in the word Stomachs corresponds to the first letter Superficialis.

In order to remember the paired erector spinae muscles and their location from lateral to medial students are recommended to study the mnemonic phrase: I Like Standing, where the first letters of each word of this sentence correspond to the first letters of muscles, namely $\mathbf{I}$ in word $\mathbf{I}$ corresponds to the first letter in Illiocostalis, $\mathbf{L}$ in the word Like corresponds to the first letter in Longissimus, $\mathbf{S}$ in the word Standing corresponds to the first letter in Spinalis.

In order to memorize the abdominal muscles, students are encouraged to study the mnemonic phrase: Spare TIRE around their abdomen, where the first letters of the word TIRE correspond to the first letters of the muscles, and the word "abdomen" indicates where these muscles are located. So $\mathbf{T}$ in the word TIRE corresponds to the first letter in Transversus abdominis, I in the word TIRE corresponds to the first letter in Internal abdominal oblique, $\mathbf{R}$ in the word TIRE corresponds to the first letter in Rectus abdomini, $\mathbf{E}$ in the word TIRE corresponds to the first letter in External abdominal oblique.

In order to memorize the layers of the scrotum, students are encouraged to study the mnemonic phrase: Some Damn Englishmen Called It The Testis, where the first letters of each word of this sentence correspond to the first letters of the scrotum layers, namely $\mathbf{S}$ in the word Some corresponds to the first letter in Skin, $\mathbf{D}$ in the word Damn corresponds to the first letter in Dartos, $\mathbf{E}$ in Englishmen corresponds to the first letter in External spermatic fascia, C in Called corresponds to the first letter in Cremaster

\section{References}

[1] Anatomy Mnemonics. Common mnemonics for medical student exams, finals, OSCEs and MRCP PACES. Oxford Medical Education. (2015). https://www.oxfordmedicaleducation.com/ medical-mnemonics/anatomy/

[2] Belimova, L. M. (2004). Использование мнемонических приемов при когнитивной обработке информации в процессе обучения студентов-медиков иностранным языкам [The use of mnemonic techniques in the cognitive processing of information in the process of teaching foreign languages to medical students]. Омский научный вестник - Omsk Scientific Bulletin, 2(27), 166-168.

[3] Bian, H., Bian, Y., Li, J., Xu, S., Shao, X., Li, J., \& Jiang, B. (2020). A simple hand mnemonic for teaching the cardiac cycle. Advances in physiology education, 44(1), 21-25. https:// doi.org/10.1152/advan.00059.2019

[4] Cherepakha, O. L., Gadzhula, N. G., \& Goray, M. A. (2019). muscle, I in It corresponds to the first letter in Internal spermatic fascia, $\mathbf{T}$ in The corresponds to the first letter in Tunica vaginalis, $\mathbf{T}$ in the word Testis corresponds to the word Testis (oxford medical) [1]

\section{Conclusions and prospects for further} development

1. This article includes mnemonics that will help to easily learn the following terms, namely the anatomy of the skeleton bones for memorizing the bones of the medial wall of the orbit, the bones in the nasal septum, the wrist bones, the ankle tarsal bones, recognition of thoracic vertebrae from the lumbar, cranial bones, upper limb bones and the order of their location from proximal to distal, bones of the lower limb and the order of their location from proximal to distal, the vertebral regions and the order of their location from the superior part of the spine to the inferior part, the hand bones and the order of their location from the distal end of the fingertips to the wrist, the arm bones and the bone projections.

2. Also included are mnemonics on the anatomy of the cranial nerves that pass through the superior orbital fissure and branches of the facial nerve, mnemonics on the anatomy of the peripheral nervous system, namely somatic nerve plexuses, which include the brachial plexus branches.

3. Also included are mnemonics on the anatomy of the upper limbs muscles, namely the muscles that form the rotator cuff in the shoulder, muscles involved in elbow flexion and the anterior flexor muscles of the forearm and mnemonics on the anatomy of the trunk muscles, namely the paired erector spinae muscles and their location from lateral to medial and abdominal muscles.

4. Finally, this article includes a mnemonic on the anatomy of the male reproductive system, namely the layers of the scrotum.

In the future, new mnemonics will be developed that relate to splanchnology, anatomy of the central nervous system, anatomy of the sensory organs and anatomy of the cardiovascular system, which were not listed above.

Мнемотехніка для кращого та швидшого запам'ятовування інформації з гістології для англомовних студентів медичного та стоматологічного факультетів [Mnemonics for better and faster memorization of histology information for English-speakingstudents of medical and dental faculties]. Вісник Вінницького національного медичного універсиmemy - Reports of Vinnytsia National Medical University, 23(3), 490-494. DOI: 10.31393/reports-vnmedical-2019-23(3)25

[5] Chung, B. S., Koh, K. S., Oh, C. S., Park, J. S., Lee, J. H., \& Chung, M. S. (2020). Effects of Reading a Free Electronic Book on Regional Anatomy with Schematics and Mnemonics on Student Learning. Journal of Korean medical science, 35(6), e42. https://doi.org/10.3346/jkms.2020.35.e42

[6] Joseph, M. A., \& Natarajan, J. (2020). The Carpal and Tarsal Bones of the Human Body: Arabic mnemonics. Sultan Qaboos 
University medical journal, 20(2), e223-e226. https://doi.org/ 10.18295/squmj.2020.20.02.014

[7] Kalish E. E. (2017). Использование принципов педагогической мнемотехники в преподавании иностранного языка [Using the principles of pedagogical mnemonics in teaching a foreign language]. Baikal Research Journal, 8(1). DOI: 10.17150/2411-6262.2017.8(1).19

[8] Murashov, О. V. (2018). Использование мнемонического обучения для улучшения академической успеваемости при изучении анатомии человека [Using mnemonic learning to improve academic performance in the study of human anatomy]. Вестник Череповецкого государственного унивepcumema - Bulletin of the Cherepovets State University, 4, 141-146. DOI: 10.23859/1994-0637-2018-4-85-17

[9] Murashov, O. V. (2019). Классификация методов и приемов мнемонического обучения анатомии человека в вузе [Classification of methods and techniques of mnemonic teaching of human anatomy at the university]. Известия РГПУ им. А. И. Герцена - Bulletin of the Russian State Pedagogical University named after A.l. Herzen, 193, 127-135.

[10] Polshchikova, A. K. (2016). Мнемоника как метод запоминания иноязычных слов [Mnemonics as a method of memorizing foreign words]. Новая наука: опыт, традиции, инновации. Международное научное периодическое издание по итогам Международной научно-практической конференции - New science: experience, tradition, innovation. International scientific periodical following the results of the International Scientific and Practical Conference, 3, 88-89.

[11] Smith, C. F., \& Border, S. (2019). The Twelve Cranial Nerves of Christmas: Mnemonics, Rhyme, and Anatomy - Seeing the Lighter Side. Anatomical sciences education, 12(6), 673-677. https://doi.org/10.1002/ase.1846

\section{ВИКОРИСТАННЯ МНЕМОТЕХНІКИ ДЛЯ КРАЩОЇ УСПІШНОСТІ СТУДЕНТІВ МЕДИЧНОГО УНІВЕРСИТЕТУ ПРИ ВИВЧЕННІ АНАТОМІЧНИХ TEPMIHIB \\ Черепаха О. Л., Гаджула Н. Г., Рекун Т. О.}

Анотація. Мнемоніка, мнемотехніка - це сукупність спеціальних способів і прийомів, які полегшують запам'ятовування потрібної інформації і збільшують обсяг пам'яті шляхом утворення асоціацій. Метою роботи є розробка методик, які допоможуть студентам медичних закладів ефективно вивчити анатомічні терміни завдяки полегшенню запам'ятовування значних обсягів інформації. У цій статті ми використовували наступні мнемонічні техніки: мнемоніка за першими літерами або акроніми, та метод "Порівняння" - виявлення спільних рис у досліджуваному і добре відомому матеріалі, а саме подібність за формою. До цієї статті увійшли мнемоніки, які допоможуть легко вивчити наступні терміни, а саме 3 анатомії кісток скелета для запам'ятовування кісток медіальної стінки очної ямки, кісток носової перегородки, кісток зап'ястка, тарзальних кісток щиколотки, розпізнавання хребців грудного відділу від поперекового, кісток черепа, кісток верхньої кінцівки, кісток нижньої кінцівки, хребтових ділянок, кісток кисті, кісток руки та випинання кісток. Також увійшли мнемоніки з анатомії черепних нервів, які проходять через верхню очноямкову щілину та гілок лицьового нерва, мнемоніки з анатомії перифьеричної нервової системи, а саме соматичні нервові сплетення, до яких входять гілки плечового сплетення. Також увійшли мнемоніки з анатомії м'язів верхніх кінцівок, а саме м'язів, які утворюють м'язово-сухожилкову структуру навколо капсули плечового суглоба, м'язів, які приймають участь у згинанні ліктя, та передній м'яз-згинач передпліччя та мнемоніки з анатомії м'язів тулуба, а саме парні м'язи-випрямлячі хребта та м'язи живота. I нарешті до цієї статmі увійшла мнемоніка з анатомії органів чоловічої статевої системи, а саме шари калитки. У перспективі будуть розроблені нові мнемоніки, які стосуються спланхнології, анатомії центральної нервової системи, анатомії органів чуття та анатомії серцево-судинної системи, що не були перераховані вище.

Ключові слова: мнемоніка, мнемотехніка, анатомічні терміни, англомовні студенти. 